\title{
Studi Deskriptif Preferensi Pemilihan Pasangan Hidup Antara Pria Dan Wanita Pada Dewasa Awal
}

\author{
Indah Puji Ratnani' ${ }^{1}$, Mukhlis ${ }^{2}$, Afni Benazir ${ }^{3}$ \\ ${ }^{1,2,3}$ Fakultas Psikologi Universitas Islam Negeri Sultan Syarif Kasim Riau \\ kurfaku@gmail.com
}

\begin{abstract}
Abstrak
Memasuki masa dewasa awal, setiap individu dihadapkan pada peran baru yaitu menikah. Untuk menjalankan peran tersebut, maka individu akan mencari hidup berdasarkan karakteristik yang dijadikan preferensi pemilihan pasangan hidup. Hal ini dilakukan untuk menghindari munculnya ketidakcocokan dalam pernikahan. Dengan demikian dilakukanlah penelitian desktriptif yang bertujuan untuk melihat gambaran preferensi pemilihan pasangan hidup antara laki-laki dan perempuan dewasa yang beragam Islam. Jumlah subjek sebanyak 400 orang, yang terdiri dari 200 orang laki-laki dan 200 orang perempuan dengan karakteristik beragama Islam dan belum menikah yang dipilih menggunakan Teknik incidental random sampling. Instrumen penelitian berupa kuisoner preferensi pemilihan pasangan yang diadaptasi dari mate preference questioner oleh Buss (1989). Data yang diperoleh dianalisis menggunakan analisis deskriptif dengan metode cross tabulation dan distribusi frekuensi. Diperoleh hasil bahwa terdapat persamaan maupun perbedaan antara laki-laki danperempuan yang beragama Islam dalam memilih calon pasangan hidup terutama berkaitan dengan karakterisktik yang ada pada diri calon tersebut. Berkaitan dengan alasan dalam memilih calon pasagan hidup, kesamaannya ditemukan pada lima belas dari delapan belas karekteristik pasangan hidup, sedangkan perbedaannya ditemukan pada tiga karekteristik. Sementara itu, berkaitan dengan prioritas karekteristik yang harus ada pada calon pasangan hidupnya, kesamaan urutan prioritas laki-laki dan perempuan hanya terjadi pada empat karekteristik dari tiga belas karekteristik pasangan hidup, sedangkan pada sembilan karekteritik lainnya laki-laki dan perempuan menempatkan urutan prioritas yang berbeda.
\end{abstract}

Kata kunci: Preferensi Pemilihan Pasangan, Pria, Wanita, Dewasa Awal

\begin{abstract}
Entering early adulthood, each individual is faced with a new role, namely marriage. To carry out this role, individuals will seek life based on the characteristics that are used as preferences for choosing a life partner. This is done to avoid the appearance of a mismatch in the marriage. Thus, a descriptive study was conducted which aims to describe the preference for life partners between men and women who are various in Islam. The number of subjects was 400 people, consisting of 200 men and 200 women with Muslim and unmarried characteristics who were selected using the incidental random sampling technique. The research instrument in the form of a partner preference questionnaire was adapted from the Mate preference questionnaire by Buss (1989). The data obtained were analyzed using descriptive analysis with cross tabulation and frequency distribution methods. The results show that there are similarities and differences between men and women who are Muslim in choosing a prospective life partner, especially with regard to the characteristics that exist in the candidate. Regarding the reasons for choosing a life partner candidate, the similarities were found in fifteen of the eighteen characteristics of a life
\end{abstract}


partner, while the differences were found in three characteristics. Meanwhile, regarding the priority characteristics that must be present in a prospective life partner, the similarity in the priority order of men and women only occurs in four of the thirteen characteristics of a life partner, while in the other nine characteristics men and women place a different priority order.

Keywords: Preference for Partner Selection, Men, Women, Early Adults

\section{Pendahuluan}

Permikahan merupakan salah satu hal penting dalam kehidupan manusia. Selain sebagai cara terbaik untuk menyalurkan kebutuhan seksual, melalui pernikahan maka pasangan suami istri akan memperoleh berbagai dampak positif baik untuk kesehatan emosional maupun fisik, seperti yang dikemukakan Gardiner \& Kosmitzk (2005); Myer (2008) bahwa dengan pernikahan akan menurunkan tingkat stress dan meningkatkan harga diri seseorang. Myer (2008) bahwa dengan pernikahan akan menurunkan tingkat stress dan meningkatkan harga diri seseorang. Hal ini dikarenakan dalam pernikahan menawarkan keintiman, komitmen, pertemanan, kasih sayang, kebersamaan, peluang untuk pertumbuhan emosional, pemenuhan kebutuhan seksual dan sumber baru bagi identitas dan harga diri seseorang (dalam Papalia, Olds dan Fildmann, 2009). Ini sesuai pula dengan firman Allah dalam Al- Qur'an surah Ar-Rum ayat 21 :

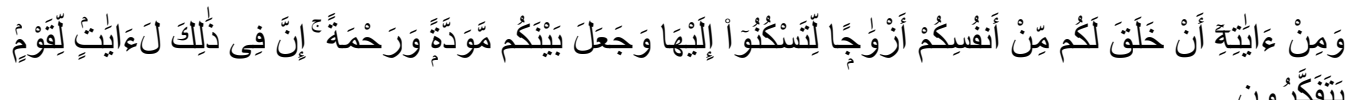
بَنَفَكَرُونُ

Artinya : Dan diantara tanda-tanda kekuasaanNya ialah Dia menciptakan untukmu isteri-isteri dari jenismu sendiri, supaya kamu cenderung dan merasa tenteram kepadanya, dan dijadikanNya diantaramu rasa kasih dan sayang. Sesungguhnya pada yang demikian itu benar-benar terdapat tanda-tanda bagi kaum yang berpikir." [QS. Ar.

\section{Ruum (30):21].}

Selain memperoleh dampak positif dari suatu pernikahan, tujuan melaksanakan pernikahan adalah memperoleh pernikahan. Sebagaimana yang terdapat tercantum dalam undang-undang perkawinan RI nomor 1tahun 1974 bab 1 pasal 1 bahwa "pernikahan adalah ikatan lahir batin antara seorang pria dengan seorang wanita sebagai suami istri dengan tujuan membentuk keluarga yang bahagia dan kekal berdasarkan ketuhanan Yang Maha Esa".

Akan tetapi terjadi peningkatan pernikahan yang tidak Bahagia dan berakhir dengan perceraian. Data yang didapat melalui Info Mahkamah Agung Republik Indonesia Direktorat Jenderal Badan Peradilan Agama (Badilag, 2015) mengungkapkan bahwa pada tahun 2015 gugatan cerai yang diterima oleh pengadilan agama di seluruh Indonesia sebanyak 334.396 gugatan dengan 255.109 perkara yang sudah dikabulkan, sedangkan isbat nikah pada tahun tersebut hanya sebanyak 51.960 dengan 45.077 isbat nikah yang telah dikabulkan. Hal ini menunjukkan bahwa pada tahun 2015 khususnya, jumlah perceraian tidak sebanding dengan jumlah pernikahan. 
Banyak alasan yang diajukan dalam perceraian, mulai dari poligami tidak sehat, krisis akhlak, kekerasan fisik, ekonomi, tidak ada tanggungjawab, tidak ada keharmonisan, dan karena adanya gangguan dari pihak ketiga. Dan diantara alasan perceraian yang diajukan, hampir rata-rata penggunggat menyampaikan alasan perceraian mereka disebabkan karena tidak adanya keharmonisan (Badilag, 2015).

Tingginya tingkat ketidakharmonisan rumah tangga dan perceraian menyebabkan sekelompok orang yang telah memasuki masa dewasa awal yang belum menikah berhatihati dalam memilih pasangan dan mulai menetapkan kriteria dalam memilih pasangan hidup. Diantara kriteria tersebut terdapat kriteria khusus dan dianggap penting yang disebut sebagai preferensi pemilihan pasangan (Buss, 2008).

Preferensi pemilihan pasangan hidup juga dapat menjadi sebuah panduan agar individu mampu memilih pasangan yang diharapkan (Buss, 2008), sebab ketika individu sudah memiliki kriteria khusus, individu dapat melakukan evaluasi terhadap calon yang diinginkan untuk menjadi pasangan hidup mereka, tidak hanya dalam hal kualitas positif tetapi juga dalam hal kualitas negatif. Preferensi tersebut kemudian menjadi pertimbangan bagi individu "apakah kelak dia dapat bertahan dan menerima kualitas positif dan negatif" dari pasangan tersebut atau tidak.

Buss (2008) menjabarkan preferensi pemilihan pasangan sebagai mekanisme psikologis yang berevolusi dalam kaitannya terhadap seleksi seksual yang dilakukan oleh individu dari zaman dahulu sampai saat ini. Individu yang merupakan nenek moyang terdahulu memilih calon pasangan hidup dengan melihat karakteristik tertentu yang dianggap potensial demi mempertahankan keturunan dan reproduksi.

Dari penelitian yang telah dilakukan, beberapa jenis preferensi pasangan hidup, yaitu (1) karakteristik yang mutlak diinginkan dan rata-rata dsetiap orang memiliki karakteristik tersebut (Kaptjin, 2011), (2) bersifat khusus berdasarkan perbedaan jenis kelamin (Buss, 1989)., (3) karkteristik yang bervariasi antar individu (Lykken, 1993), (4) karakteristik bervariasi berdasarkan budaya (Buss, 1985).

Beberapa penelitian telah dilakukan terkait dengan preferensi pemilihan pasangan hidup, diantaranya Penelitian yang dilkukan oleh Buss dan Angleitner (1989) terhadap pria dan wanita German dan Amerika menemukan wanita German maupun Amerika sama-sama memberikan nilai yang tinggi pada karakteristik yang memiliki kapasitas produktivitas yang baik. Sedangkan pria German memberikan penilaian yang tinggi pada karateristik ibu rumah tangga yang baik, dan pria Amerika memberikan daya tarik fisik pada nilai tertinggi. Sementara itu Todosijevic, Ljubinkovic dan Arancic (2003) dalam penelitiannya menemukan bahwa preferensi pemilihan pasangan hidup antara pria maupun wanita memiliki perbedaan, khususnya dalam hal penilaian karakteristik berupa sifat negatif maupun karakteristik fisik. Pria cenderung memilih fisik dan tidak mempermasalahkan sifat negatif calon pasangannya, sebaliknya wanita memilih melihat sifat positif calon pasangan daripada fisiknya. 
Selain antara pria dan wanita memiliki perbedaan preferensi dalam pemilihan pasangan, berdasarkan hasil penelitian juga ditemukan "apa yang menjadi karekteristik preferensi pemilihan pasangan hidup antara pria dan wanita selalu mengalami perubahan pada setiap dekade".

Penelitian tentang preferensi pemilihan pasangan hidup juga sudah pernah diteliti di Indonesia, diantaranya dilakukan oleh Buss, yaitu ketika dia melakukan penelitian dengan mengambil sabjek dari 37 kebudayaan di 33 negara pada 6 benua dan 5 negara kepulauan. Indonesia menjadi salah satu negara kepulauan yang dijadikan sampel dalam penelitian itu, namun penelitian itu dilakukan sudah cukup lama yaitu tahun 1989. Sebagaimana telah dikemukan di atas, hasil penelitian yang dilakukan oleh penelitipeneliti sebelumnya menunjukkan bahwa pada setiap dekade, preferensi pemilihan pasangan hidup seringkali mengalami perubahan dari waktu kewaktu. Selain Buss, penelitian terbaru dilakukan oleh Lannakita (2012) dan Larasati (2012), akan tetapi keduanya hanya meneliti preferensi pemilihan pasangan hidup pada wanita dan tidak menjadikan pria sebagai sampelnya.

Penelitian yang dilakukan Buss (1989) dan Sprecher (1994) menemukan bahwa wanita dianggap cenderung memilih calon pasangan dengan melihat status sosial, jenjang pendidikan, dan pendapatan finansial dari seorang pria. Sedangkan pria cenderung melihat kepada karakteristik yang berhubungan dengan daya tarik fisik seperti kecantikan, kesehatan, bentuk tubuh, dan usia yang jauh lebih muda darinya. Penelitian ini menunjukkanbaik pria dan wanita memiliki pertimbangan yang berbeda dalam menentukan preferensi pemilihan pasangan hidupnya, wanita lebih cenderung kepada status sosial, sedangkan pria lebih kepada daya tarik fisik

Perspektif struktur sosial melihat perbedaan jenis kelamin dalam preferensi pemilihan pasangan hidup sebagai hasil dari interaksi kelas dan ketidaksetaraan gender, hubungan dominasi gender, dan ideologi patriarki (Eagly dalam Todosijevic, 2003). Artinya perbedaan yang terjadi dalam preferensi pemilihan pasangan berasal dari perbedaan dalam posisi dan peran sosial antara laki-laki dan perempuan.

Dalam sebuah hadits, juga disebutkan ada kriteria yang bisa digunakan sebagai preferensi dalam memilih pasangan, yaitu hadits dari Abu Hurairah RA, Rasulullah SAW bersabda yang artinya: "Perempuan dinikahi karena empat faktor. Karena hartanya, nasabnya, kecantikannya dan karena agamanya. Maka menangkanlah wanita yang mempunyai agama, engkau akan beruntung." (HR. Bukhari, Muslim, al-Nasa'i, Abu Dawud Ibn Majah Ahmad ibn Hanbal, dan al-Darimi).

Mengacu pada hadits nabi di atas, walaupun dalam memilih pasangan hidup dibolehkan menjadikan penampilan fisik, keturunan dan harta kekayaan sebagai preferensi dalam memilih pasangan hidup, namun sangat dianjurkan menjadikan agama sebagai prioritas utama, baik pada pria maupun wanita. Dengan konsep ini seharusnya bias gender dalam preferensi pemilihan pasangan hidup antara pria dan wanita yang 
beragama islam sebagaimana ditemukan dalam beberapa penelitian sebelumnya tidak akan terjadi. Inilah hal utama yang akan dibuktikan dalam penelitian ini.

\section{Metode}

Preferensi pemilihan pasangan hidup di dalam penelitian ini diartikan sebagai kriteria atau karakteristik tertentu yang diprioritaskan oleh seorang laki-laki dan wanita dewasa yang beragama islam dalam memilih pasangan hidup. Dalam penelitian ini yang menjadi populasi adalah pria dan wanita dewasa awal yang beragama islam dengan usia di atas 22 tahun yang belum menikah dan berdomisili di Kecamatan Tampan. Adapun jumlah sampel sebanyak 400 subjek dengan rincian 200 pria dewasa dan 200 wanita dewasa yang beragama Islam. Dan teknik pengambilan sampel menggunakan teknik insidental sampling. Hal ini dikarenakan tidak diketahuinya karateristik dari subjek penelitian.

Pengumpulan data dalam penelitian ini didapatkan dari instrument penelitian yang peneliti gunakan sebagaian alat bantu dalam mengumpulkan data penelitian. Instrument yang digunakan dalam penelitian ini adalah kuesioner tertutup.

Dasar acuan kuesioner preferensi pemilihan pasangan hidup ini menggunakan teori yang dikemukakan oleh Buss (1989) dan merupakan kuesioner hasil dari modifikasi mate selection questioner (kuesioner pemilihan pasangan). Instrumen preferensi pemilihan pasangan hidup terbagi menjadi 2, yaitu instrumen pertama berisi alasan dalam memilih pasangan hidup dan yang kedua berisi preferensi tentang calon pasangan hidup yang dianggap potensial. Instrumen pertama terdiri dari 3 bagian yaitu mengenai data biografi seperti usia, agama, jenis kelamin, status pernikahan dan pendidikan formal yang pernah diikuti; bagian kedua tentang usia yang diinginkan untuk menikah dan perbedaan usia dengan pasangan hidup; bagian ketiga responden diminta untuk meranking 18 karakteristik yang penting dalam memilih pasangan hidup dengan nilai 3 (sangat penting dan sangat dibutuhkan), 2 (penting, tetapi tidak terlalu dibutuhkan), 1 (diinginkan, tetapi tidak terlalu dibutuhkan), 0 (tidak pentingdan tidak dibutuhkan).

Pada instrumen kedua responden diminta meranking 13 karakteristik yang diinginkan untuk menjadi pasangan hidup. Ranking berupa pemberian skor 1 = sangat diinginkan hingga 13 tidak diinginkan, artinya setiap subjek memiliki hak respon sebanyak 91 respon.

Teknik analisis data yang digunakan untuk mengetahui gambaran preferensi pemilihan pasangan hidup antara pria dan wanita adalah dengan menggunakan Analisis crosstab dan distribusi frekuensi.

\section{Hasil}

Bagian pertama kuesioner meminta subjek untuk menilai 13 karakteristik yang menjadi alasan subjek dalam pemilihan pasangan hidup dengan cara merating untuk 
melihat apa saja karakteristik yang dianggap sangat penting dan sangat dibutuhkan, penting tetapi tidak terlalu dibutuhkan, diinginkan tetapi tidak terlalu dibutuhkan, dan karakteristik yang dibutuhkan. Hasil dari penilaian tersebut dapat dilihat pada rentang ranking preferensi pemilihan pasangan hidup dapat dilihat pada gambar berikut:

Gambar 1

\begin{tabular}{|c|c|c|c|c|c|}
\hline \multicolumn{5}{|c|}{ Daftar Karakteristik Prioritas Pemilihan Pasangan Hidup Berdasarkan Jenis Kelamin } & \multirow[b]{2}{*}{ No } \\
\hline No & kartakteristik & Laki-Laki & Perempuan & Karakteristik & \\
\hline 1 & Religius & $11.80 \%$ & $13.20 \%$ & Religius & 1 \\
\hline 2 & Baik dan Pengertian & $11.20 \%$ & $11.20 \%$ & Baik dan Pengertian & 2 \\
\hline 3 & Cerdas & $9.40 \%$ & $9.20 \%$ & $\begin{array}{l}\text { Berasal dari Keluarga atau Keturunan yang } \\
\text { Baik }\end{array}$ & 3 \\
\hline 4 & Berasal dari Keluarga atau Keturunan yang Baik & $9.30 \%$ & $9.20 \%$ & Cerdas & 4 \\
\hline 5 & Mampu Mengurus Rumah dengan Baik & $8.30 \%$ & $8.20 \%$ & Sehat Jasmani & 5 \\
\hline 6 & $\begin{array}{r}\begin{array}{r}\text { Memiliki Penampilan Fisik yang Menarik } \\
\text { (Cantik/Tampan) }\end{array} \\
\end{array}$ & $8.20 \%$ & $8.10 \%$ & Berkepribadian Menarik & 6 \\
\hline 7 & Menginginkan dan Sayang kepada Anak-anak & $8.20 \%$ & $8.00 \%$ & Mapan Secara Finansial & 7 \\
\hline 8 & Berkepribadian Menarik & $7.90 \%$ & $7.90 \%$ & $\begin{array}{l}\text { Menginginkan dan Sayang kepada Anak- } \\
\text { anak }\end{array}$ & 8 \\
\hline 9 & Sehat Jasmani & $7.30 \%$ & $5.70 \%$ & Lulusan Universitas & 9 \\
\hline 10 & Easy Going (Orang yang Simpel) & $4.90 \%$ & $5.40 \%$ & Easy Going (Orang yang Simpel) & 10 \\
\hline 11 & Lulusan Universitas & $4.70 \%$ & $5.10 \%$ & $\begin{array}{l}\text { Memiliki Penampilan Fisik yang Menarik } \\
\text { (Cantik/Tampan) }\end{array}$ & 11 \\
\hline 12 & Mapan Secara Finansial & $4.70 \%$ & $4.50 \%$ & Mampu Mengurus Rumah dengan Baik & 12 \\
\hline 13 & Kreatif dan Memiliki Jiwa Seni & $4.10 \%$ & $4.30 \%$ & Kreatif dan Memiliki Jiwa Seni & 13 \\
\hline & Total & $100.00 \%$ & $100.00 \%$ & Total & \\
\hline
\end{tabular}

\section{Kesimpulan}

Berdasarkan hasil penelitian yang telah dilakukan dapat disimpulkan bahwa terdapat persamaan dan perbedaan antara pria dan wanita dalam preferensi pemilihan pasangan hidupnya.

Dalam pemilihan karekteristik pasangan hidup, ada beberapa karekteristik pasangan hidup yang urutan prioritasnya sama antara pria dan wanita yaitu relegius ditempatkan pada prioritas urutan pertama, baik dan pengertian pada prioritas kedua dan kreatif serta memiliki jiwa seni sebagai prioritas terakhir.

Pria dan wanita juga memerlukan beberapa karekteristik yang harus ada pada pasangannya, namun menempatkan pada urutan prioritas yang berbeda. Karekteristik yang mempati urutan prioritas yang berbeda antara pria dan wanita adalah cerdas, berasal dari keluarga atau keturunan yang baik, lulusan universitas, berkepribadian menarik, mapan secara finansial, memiliki penampilan fisik yang menarik, mampu mengurus rumah, menginginkan dan sayang pada anak, sehat secara jasmani dan orangnya simpel.

Dalam memilih pasangan, pria dan wanita memiliki beberapa alasan yang dikategorikan sangat penting yang harus dimiliki pasangannya, yang dengan alasan itu seorang pria atau wanita akan menjadikannya sebagai pasaangan hidupnya. Alasan yang dikategirikan sangat penting itu adalah memiliki latar belakang agama yang sama, saling tertarik atau mencintai, punya keinginan memiliki rumah dan anak, perawan atau perjaka, 
menyenangkan, sehat fisik atau mental, stabil secara emosional dan memiliki kemampuan sosial yang baik.

\section{Referensi}

Al-quran,2016,Kementerian Agama Republik Indonesia:Cordoba

Badilag, 2015. http://www.Infoperkara.badilag.net/ diakses pada08 Desember 2015.

Balkanlionglu, 2011, Questuoning the Relationship Between Religion and Marriage: does Religion Effect Long-lasting Marrarrige? Turkish Couples Practice, Percption, and Attitudes Towards Religion and Marriage. Uluslararasi Sasyal Aratirmalar Dargisi The Journal Of International Social Research. 7 31, 515-523.

Barnes \& Buss, 1986. Preferences in Human Mate Selection.Journal of Personality and Social Psychology, Vol. 50, No. 3, 559-570.

Buss, M.D. 1985. Human mate selection. American Scientist, 73, 47-51. 1989. Sex Differences in Human Mate Preference: Evolutionary Hypotheses Test in 37 Cultures. Behavioral and Brain Science. 1-49. 1990. International Preferences in Mate Selection: A Study of 37 Cultured. Journal of Cross Cultural Psychology, Vol. 21 No. 1. 5-47.

2006. Strategies of Human Mating. Original Scientific Article Psychological Topics $15,2,239-260$.

2008. Evolutionary Psychology (3rd edition). United state of America: Pearson Education, Inc.

Buss, M.D. \&Angleitner, A. 1989. Mate Selection Preferences in Germany and United Stated.Person. In \& id.D Vol.10, No. II. pp. 1269-1280.

Degenova, K.M. 2008. Intimate Relationship Marriages \& Families, (7th edition). New York: The McGraw-Hill Companies, Inc.

Fisman, R.I., Sheena.S, Kamenica., E. \& Simonson, I. 2006. Gender Differences In Mate Selection: Evidence From A Speed Dating Experiment. The Quarterly Journal of Economics.

Kaptijn, R. 2010. Testing Six Mate Preference Theories; Mate Preferences and Judgments in Mate Selection Process. (Thesis) of Master Social System Evaluation and Survey Research.

Lannakita, 2012. Hubungan Self Esteem dan Preferensi Pemilihan Pasangan Hidup Pada Wanita Dewasa Muda di Jabodetabek. (Skripsi)Fakultas Psikologi Universitas Indonesia.

Larasati, D. 2012. Perbedaan Preferensi Pemilihan Pasangan Hidup Pada Wanita Bekerja dan Tidak Bekerja. (Skripsi)Fakultas Psikologi Universitas Indonesia.

Lykken, T.D., \& Tellegen, A. 1993. Is Human Mating Adventitious or the Result of Lawful Choice? A Twin Study of Mate Selection. Journal of Personality and Social Psychology. Vol.6. No.1, 56-68.

Myers, G. David. 2012. Psikologi Sosial. Jakarta Selatan: Salemba Humanika.

Nazir, M. 2002. Metode Penelitian. Jakarta: Ghalia Indonesia.

Rahman, S. 1001 Hadist yang Menggugah. 2010. Jakarta: Pustaka Ikadi.

Papalia, dkk, 2008. Human Deveolpmen (Psikologi Perkembangan), Jakarta: Kencana 
Schustack, W. M., \& Friedman, S. H., 2006. Kepribadian Teori Klasik dan Riset Modern. Edisi ketiga jilid 2. Jakarta: Erlangga.

Soebijanto, \& Sriudiyani A. Ida. 2011. Perkawinan Muda Dikalangan Perempuan : Mengapa..? Seri I No.6/Pusdu-BKKBN/Desember 2011. Diunduh pada 04 April 2015.

Sprecher. S, Sullivan. Q, \& Hatfield. E. Mate Selection Preferences: Gender Diffrences Examined in a National Sample. 1994. Journal of Personality and Social Psychology. Vol. 66. No. 6, 1074-1080.

Taylor, E.S., Letitia A Peplau, A.L., Sears, O.D. 2009. Psikologi Sosial (edisi 12). Jakarta: Prenada Media Group.

Todosijevic. B, Ljubonkovic. S, \& Arancic. A. 2003. Mate selection criteria: A trait desirability assessment study of sex differences in Serbia. Original Artical of Evolutionary Psychology. human-nature.com/ep. 1: 116-126.

Townsend, M. Jhon., Robert, W. Laurence. 1993. Gender Deferences in Mate Preference Among Law Student; Divergence and Convergence of Criteria. The Journal of Psychology 127 (5), 507-528 